\title{
Flexural Strength of Interlocking Compressed Earth Brick (ICEB) Unit
}

\author{
S. Saari ${ }^{1 *}$, B. H. Abu Bakar ${ }^{*}$, and N. A. Surip ${ }^{2}$ \\ ${ }^{1}$ School of Civil Engineering, Universiti Sains Malaysia, Engineering Campus, 14300 Nibong Tebal, Penang, \\ Malaysia \\ ${ }^{2}$ ICEB Trading, Lot 223, Padang Temusu, 08000 Sungai Petani, Kedah, Malaysia \\ *Corresponding author: syahmii5s@gmail.com and cebad@usm.my
}

\begin{abstract}
This paper presents the flexural strength of the ICEB unit. The flexural strength is important in determining the strength of the masonry unit. About 260 units of ICEB consist three type of unit were tested on flatwise (bed direction) and inverted direction, with the different shape at the top and bottom of the ICEB. The unit was loaded at midspan through a steel bearing plate of $6.4 \mathrm{~mm}$ thickness and $38.1 \mathrm{~mm}$ width. Specimens were supported at both ends which are free to rotate in the longitudinal and transverse directions during the test. The highest flexural strength of ICEB is Wall Brick for both flatwise and inverted direction which is 2.36 $\mathrm{N} / \mathrm{mm}^{2}$ and $2.15 \mathrm{~N} / \mathrm{mm}^{2}$, respectively. For flatwise direction, Beam Brick has the lowest flexural strength which is $1.55 \mathrm{~N} / \mathrm{mm}^{2}$, and in inverted direction Column Brick flexural strength is lower than Beam Brick which is 1.65 $\mathrm{N} / \mathrm{mm}^{2}$. ICEB can be used in construction and has the equal properties as other common brick and block at the market nowadays.
\end{abstract}

Keywords_Masonry; Compressed earth brick; Interlocking; Mechanical properties; Dry stack.

\section{INTRODUCTION}

C onstruction industry requires materials which can speed up the construction time to reduce the cost of the construction. Meanwhile, using conventional bricklaying method consumes high cost and time because using a lot of mortar and need to use formwork for the structural work. Conventional bricklaying method also needs a skilled worker to ensure the bricklaying is flat and fast. Interlocking compressed earth brick (ICEB) is the solution to reduce the time and cost of construction. ICEB also can reduce the use of skilled worker, and this advantage makes ICEB more practical to use in construction.

Interlocking Compressed Earth Brick (ICEB) consist four basic materials which are soil, cement, sand, and water. ICEB manufacturing just required low skill worker since it is simple to produce which only takes three stage of the process which is soil preparation, mix compression and curing [1]. Proper compression is needed to make good ICEB strength and ICEB curing only by open-air.

ICEB has dowels for interlocking joints and holes for grout and reinforcement. ICEB allow the bricks to be dry stacked without mortar by creating interlocking joints between layers of bricks. Grout will be poured into the holes after ICEB were stacked. An inexperienced labor can easily use the ICEB because of it is easier to connect between brick compared to conventional bricklaying method which the labor need to spread the mortar evenly, so the bricklaying is flat. ICEB can fasten the time in construction by removing work for installation and opening the formwork for beam and column because ICEB itself can be beam and column. Reinforcement for column and beam will be placed inside of the ICEB itself using a certain type of ICEB.

Flexural strength of the masonry brick can be important properties in masonry as compressive strength to guide the engineer to select of good materials in construction. Flexural strength can give two parameters that are the ultimate flexural strength or modulus of rupture, which is determined by the maximum load that can be attained and first cracks strength, which is primarily controlled by the matrix [2]. A study by Silva et al about flexural strength of dry-stack masonry made by compressed earth block (CEB) stabilized with alkaline activation shows CEB with percentage of $15 \%$ fly ash from soil has higher flexural strength than $10 \%$ fly ash which is $2.3 \mathrm{~N} / \mathrm{mm}^{2}$ and $1.8 \mathrm{~N} / \mathrm{mm}^{2}$, respectively [3]. Another study by Muntohar [4] about engineering characteristic of the compressed stabilized earth brick shows flexural strength of brick with $70 \%$ clay and $30 \%$ sand proportion is $0.22 \mathrm{~N} / \mathrm{mm}^{2}$, and addition of $5 \%$ lime and $5 \%$ rice husk ash to the $70 \%$ clay and $30 \%$ sand proportion make flexural strength of the brick to 0.56 $\mathrm{N} / \mathrm{mm}^{2}$. Walker stated that flexural strength of block was closely correlated with soil and cement content [5]. Flexural strength increase when soil content decrease from $0.13 \mathrm{~N} / \mathrm{mm}^{2}$ for $100 \%$ soil content to $0.71 \mathrm{~N} / \mathrm{mm}^{2}$ for $15 \%$ soil content of stabilized soil block. Walker also supports his result in another study that flexural strength of compressed earth block improved with cement addition from $1.37 \mathrm{~N} / \mathrm{mm}^{2}$ to $3.58 \mathrm{~N} / \mathrm{mm}^{2}$ with $0 \%$ of cement to $10 \%$ of cement [6].

Interlocking Compressed Earth Brick is a new construction material in Malaysian construction industry. Currently, usage and production of Interlocking Compressed Earth Brick (ICEB) are available in Malaysia, but there are no physical and mechanical 
properties about ICEB can be discovered. This paper focuses on the flexural strength of the ICEB.

\section{METHOD}

\section{A. Materials}

ICEB which been used in this study were manufactured locally by ICEB Trading located at Sungai Petani, Kedah. They manufactured thirteen type of brick, but only three type of brick in ICEB were used in this study. This three type of brick is Wall Brick, Beam Brick, and Column Brick. Wall Brick and Beam Brick were made by hydraulic compression machine meanwhile Column Brick was made by manual hand compress. ICEB size and shape are variable according to the function and location which it will be placed and the common size of ICEB $250 \mathrm{~mm}$ length, $125 \mathrm{~mm}$ width, and height of 100 $\mathrm{mm}$. Figure 1 shows three type of the ICEB used in this study.

\section{B. Testing procedure}

In this study, about 260 units of three type of ICEB were used to study their flexural strength. From 260, a total of 100 units are Wall Brick and 80 units each from Beam and Column Brick. All tested masonry units were sampled at random as prescribed in clause 9 of BS 3921 [2].

For this study, all 260 units were divided into two sides of test which is flatwise (bed direction) and inverted

direction accordance ASTM C67 [4]. ICEB were tested on two sides because ICEB has a different shape at the top and bottom side. The load will be placed at midspan of the brick through a steel bearing plate $6.4 \mathrm{~mm}$ in thickness and $38.1 \mathrm{~mm}$ in width and length equal to the width of the specimen. The specimen was supported at

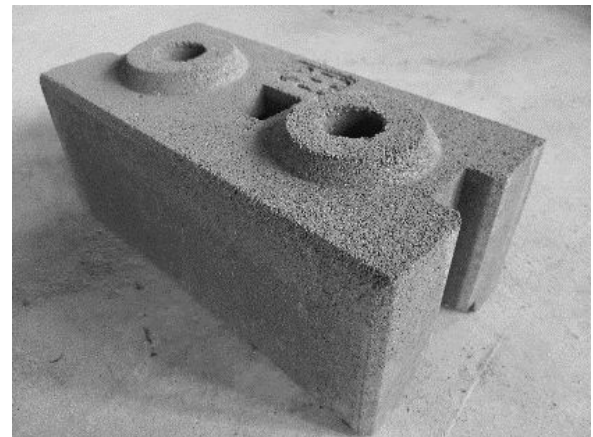

(a) both ends which are free to rotate in the longitudinal and transverse directions during the test. This procedure is aimed to force the failure surface to occur in the middle span. All sample were oven dried for 24 hours before the test to have a constant mass in ICEB units. The distance from the plane of failure to the midspan of the specimen towards the span was measured to calculate the flexural strength of the ICEB. The calculation of flexural strength as followed:

$S=3 W(l / 2-x) / b d^{2}$

Where $S$ is the flexural strength, $W$ is maximum applied load, $l$ distance between support, $b$ and $d$ is width and depth of the specimen, and $x$ is a distance from the plane of failure to the midspan.

\section{RESULTS AND DISCUSSION}

All the experiment conducted to determine the flexural strength of the ICEB was done at the laboratory. Figure 2 shows the brick failure after flexural strength test. All ICEB unit from Wall Brick, Beam Brick and Column Brick were failed in the tensile crack as shown in Figure 2. In Figure 3, it shows the graph of flexural strength in flatwise direction for all 130 units of ICEB units. As it can be seen, the graph distribution for ICEB flexural strength is variable. In flatwise direction, the surface which has dowel is at the top and surface with the groove is at the bottom. Figure 4 shows the graph of the average flexural strength of ICEB at flatwise (bed direction). From table 1, Wall Brick has the highest flexural strength which is $2.36 \mathrm{~N} / \mathrm{mm}^{2}$, followed by Column Brick which is $2.00 \mathrm{~N} / \mathrm{mm}^{2}$ and Beam Brick has the lowest flexural strength which is $1.55 \mathrm{~N} / \mathrm{mm}^{2}$. In flatwise direction, $x$ ( distance from the plane of failure to the midspan) value for Wall Brick and Beam Brick is similar compared to Column Brick which has the higher value. The value of $x$ can significantly affect the flexural

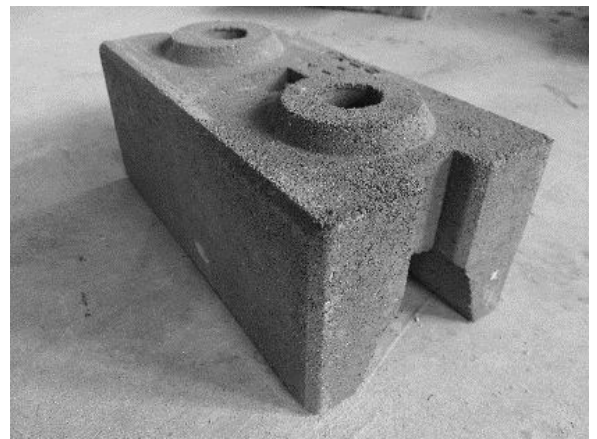

(b)

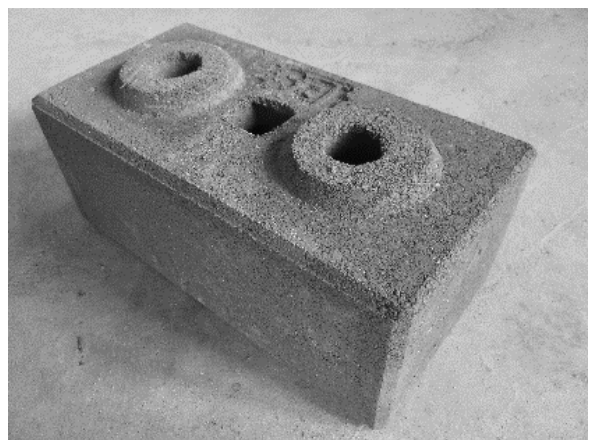

(c)

Figure 1: Example of ICEB (a) Wall Brick, (b) Beam Brick, (c) Column Brick 
The Third International Conference on Civil Engineering Research (ICCER)

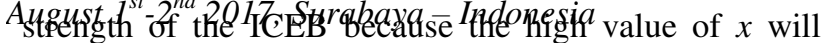
result in low flexural strength. Although Column Brick has highest $x$ value, it has higher flexural strength than flatwise direction because it has the deeper groove at the bottom of the brick compared to the Wall Brick and Column Brick. Deep groove under the Beam Brick

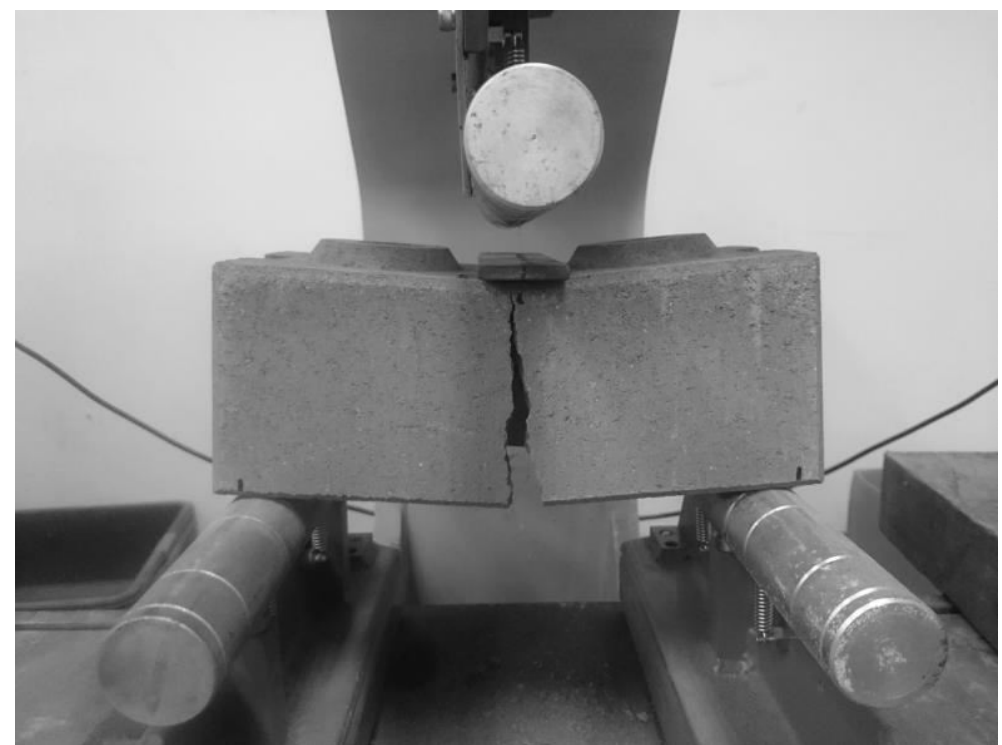

Figure 2: Brick after flexural strength test in flatwise direction.

Beam Brick. It is because Beam Brick has lower failed load compared to Wall Brick and Column Brick. Beam brick has the lowest flexural strength in makes it has a less surface on the support and more void under the brick compared to the Wall Brick and Column Brick.

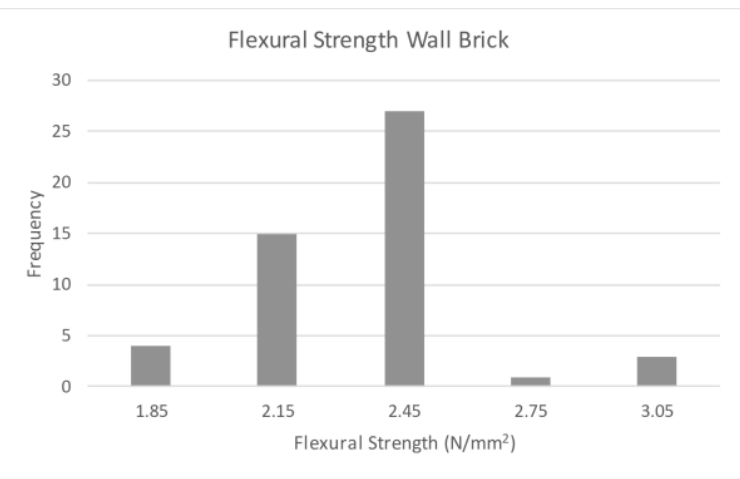

(a)

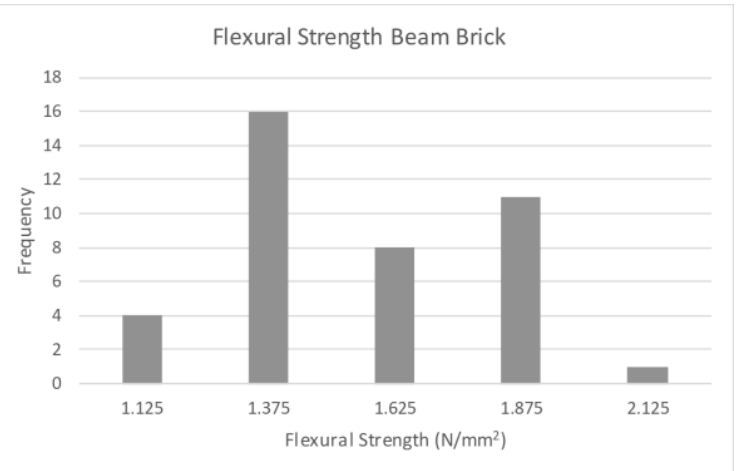

(b)

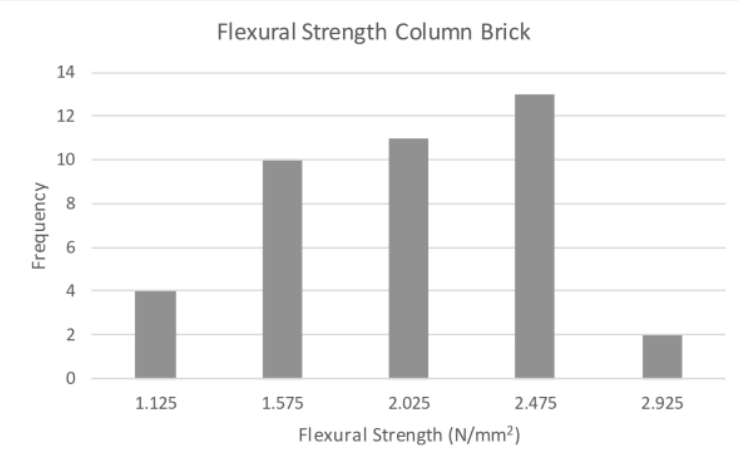

(c) 


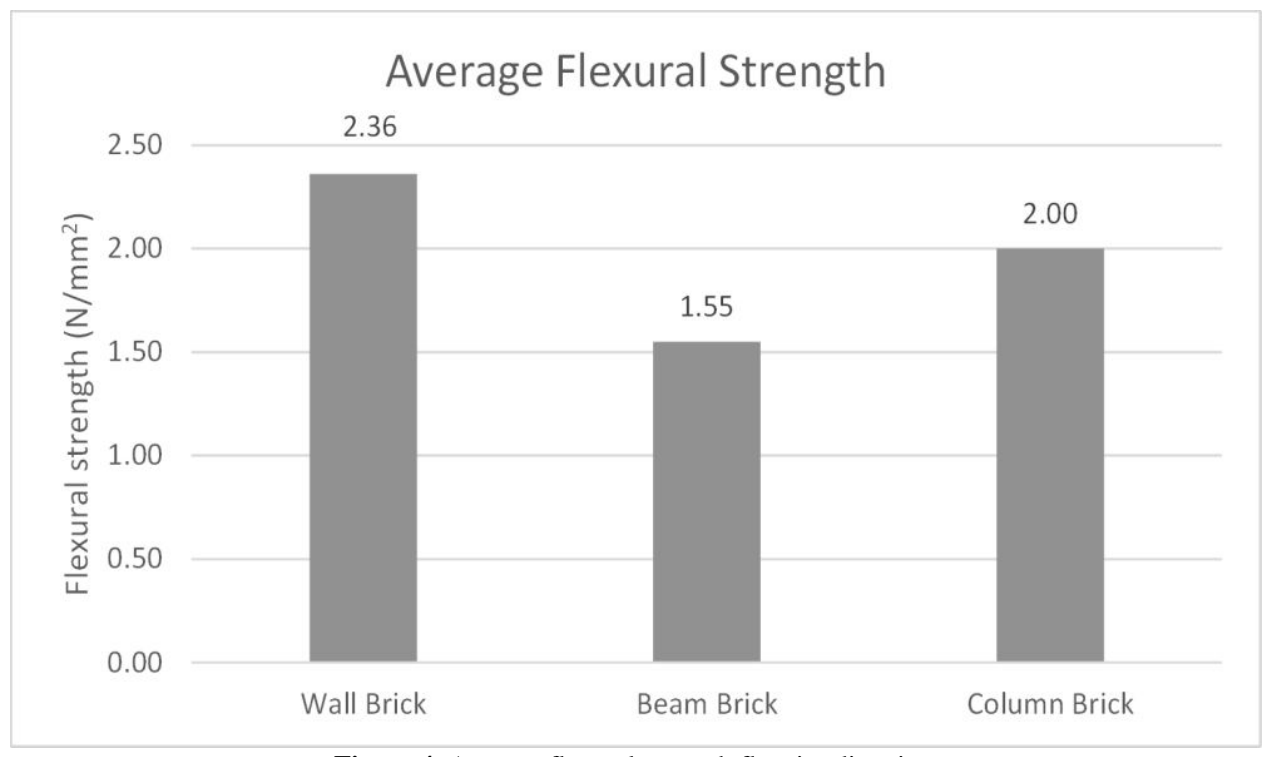

Figure 4: Average flexural strength flatwise direction.

Table 1.

Flexural strength flatwise direction.

\begin{tabular}{lccccc}
\hline Brick type & $\begin{array}{c}\text { Average strength } \\
\left(\mathrm{N} / \mathrm{mm}^{2}\right)\end{array}$ & $\begin{array}{c}\text { Standard } \\
\text { deviation }\end{array}$ & $\begin{array}{c}\text { COV } \\
(\%)\end{array}$ & $\begin{array}{c}\text { Average } \\
x\end{array}$ & $\begin{array}{c}\text { Range } \\
\left(\mathrm{N} / \mathrm{mm}^{2}\right)\end{array}$ \\
\hline Wall Brick & 2.36 & 0.28 & 11.99 & 10.32 & $1.75-3.12$ \\
Beam Brick & 1.55 & 0.26 & 16.67 & 10.85 & $1.08-2.02$ \\
Column Brick & 2.00 & 0.50 & 25.18 & 19.79 & $0.93-2.86$ \\
\hline
\end{tabular}

Result for flexural strength of 130 units of the ICEB in inverted direction was shown Figure 5. In this direction, ICEB were place inverted than normal side. Surface with dowel was placed at bottom and surface with groove were placed at the top. The graph distribution for the ICEB flexural strength also can be seen variable in this direction. Figure 6 and Table 2 shows the average of flexural strength of Wall Brick, Beam Brick, and Column Brick. For this direction, Wall Brick still has the highest flexural strength which is 2.15 $\mathrm{N} / \mathrm{mm}^{2}$, followed by Beam Brick, $1.90 \mathrm{~N} / \mathrm{mm}^{2}$, and the lowest flexural strength is Column Brick which is 1.65 $\mathrm{N} / \mathrm{mm}^{2}$. The $x$ value in this direction is lower compared to the flatwise direction and not significantly different with each type of the ICEB. The highest $x$ value is on Wall Brick, and the lowest value is on Beam Brick. Although Wall Brick has the highest value of $x$, it has the highest flexural strength compared to the others brick. The reason Column Brick has the lowest flexural strength in this direction is that Column Brick is made from manual hand compress, the compression rate of manual hand compress is lower than hydraulic compression machine. The topside of Column Brick is not fully compacted compared to Wall Brick and Beam Brick because of the low rate compression.

From this study, it can be seen that ICEB in flatwise direction has higher flexural strength than inverted direction. Although flatwise direction has higher $x$ value compared to the inverted direction, ICEB in flatwise direction has higher flexural strength. This because the bottom side of the ICEB is more compacted compared to the top side. All flatwise and inverted flexural strength is higher than minimum flexural strength stated by Silva et al [8] which is $0.25 \mathrm{~N} / \mathrm{mm}^{2}$. 
The Third International Conference on Civil Engineering Research (ICCER)

A

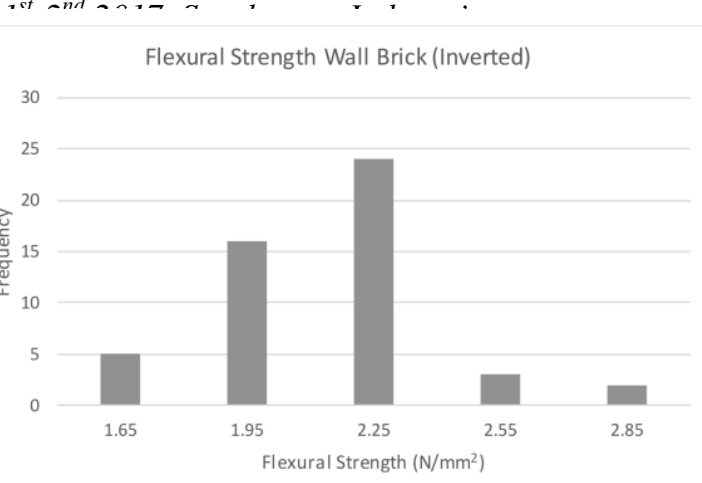

(a)

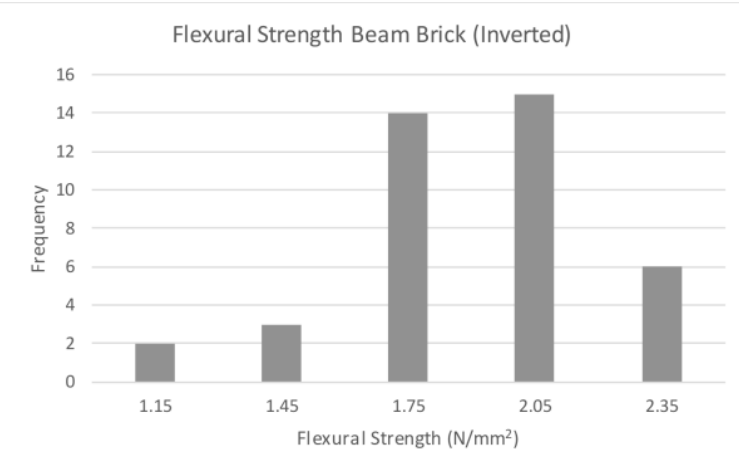

(b)

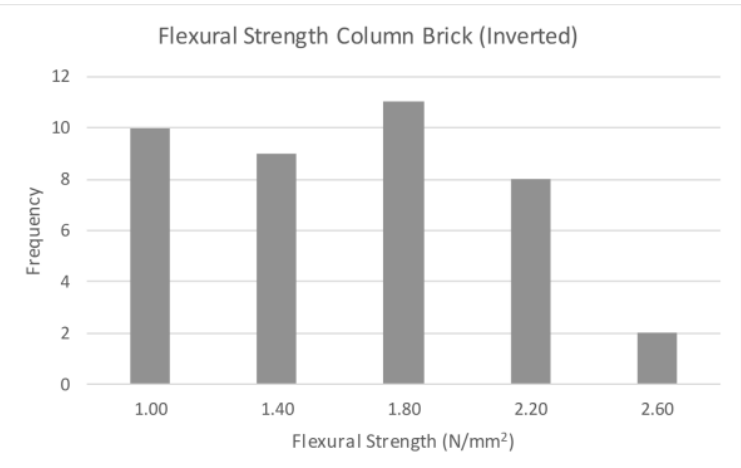

(c)

Figure 5: Result in flexural strength in inverted direction for (a) Wall Brick, (b) Beam Brick, (c) Column Brick.

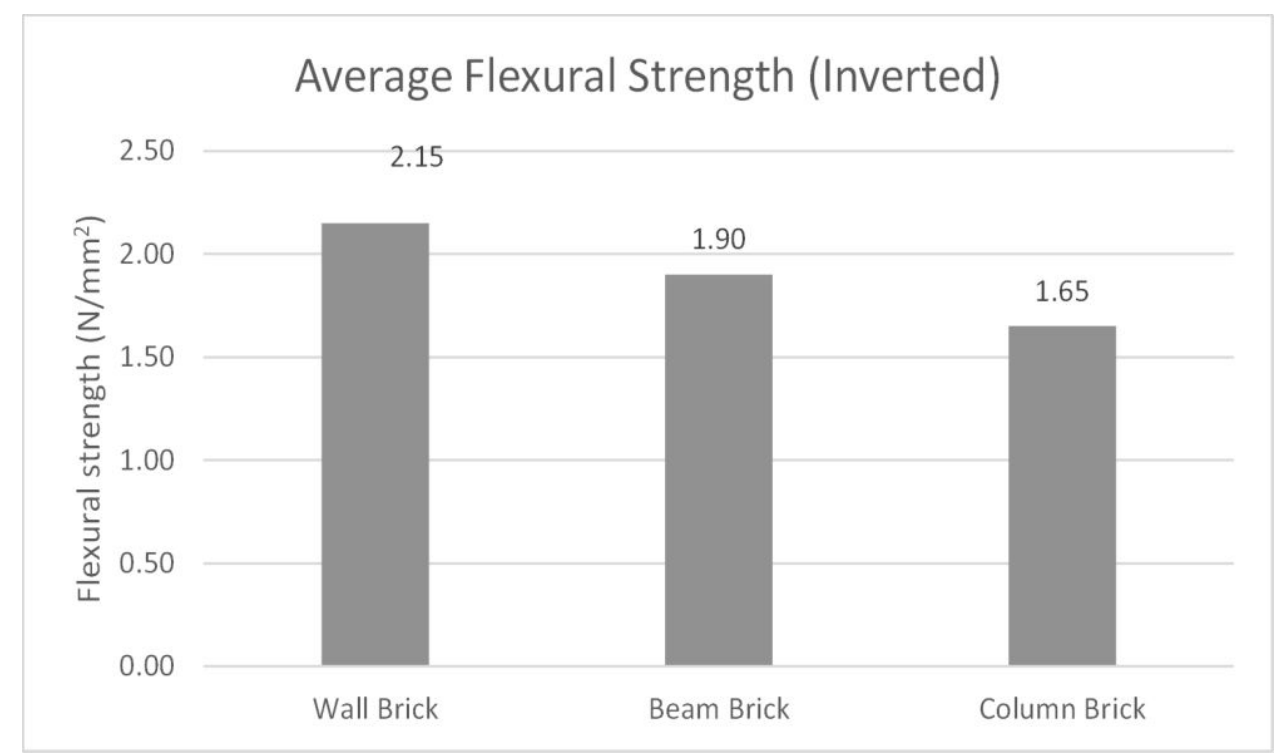

Figure 6: Average flexural strength inverted direction.

Table 2.

Flexural strength inverted direction.

\begin{tabular}{lccccc}
\hline Brick type & $\begin{array}{c}\text { Average strength } \\
\left(\mathrm{N} / \mathrm{mm}^{2}\right)\end{array}$ & $\begin{array}{c}\text { Standard } \\
\text { deviation }\end{array}$ & $\begin{array}{c}\text { COV } \\
(\%)\end{array}$ & $\begin{array}{c}\text { Average } \\
x\end{array}$ & $\begin{array}{c}\text { Range } \\
\left(\mathrm{N} / \mathrm{mm}^{2}\right)\end{array}$ \\
\hline Wall Brick & 2.15 & 0.28 & 12.94 & 5.16 & $1.52-2.90$ \\
Beam Brick & 1.90 & 0.29 & 15.36 & 3.55 & $1.20-2.45$ \\
Column Brick & 1.65 & 0.48 & 28.82 & 3.91 & $0.88-2.55$ \\
\hline
\end{tabular}

IV. CONCLUSION

This paper shows the result of Interlocking Compressed Earth Brick (ICEB) flexural strength from the laboratory investigation. The highest flexural strength of ICEB is 
Wall Brick for both flatwise and inverted direction which is $2.36 \mathrm{~N} / \mathrm{mm}^{2}$ and $2.15 \mathrm{~N} / \mathrm{mm}^{2}$. For flatwise direction, Beam Brick has the lowest flexural strength which is $1.55 \mathrm{~N} / \mathrm{mm}^{2}$ because it has the deeper groove at the bottom of the brick compared to the other bricks. In inverted direction, Column Brick has lower flexural strength than Beam Brick because of the difference in compactness at the top of the brick. Beam Brick is manufactured by hydraulic compression machine, so it is more compact compared to Column Brick which is made by manual hand compress. Flexural strength of the ICEB in the flatwise direction is higher than flexural strength in the inverted direction. All flatwise and inverted flexural strength can be used in the construction because it is higher than minimum flexural strength which is 0.25 $\mathrm{N} / \mathrm{mm}^{2}$.

\section{ACKNOWLEDGMENT}

The authors would like to thank ICEB Trading for supplying materials used for this study.

\section{REFERENCES}

[1] C. Bales, C. Donahue, M. Fischer, A. Mellbom, and T. Pearson, "Interlocking Compressed Earth Blocks: From Soil to Structure," 2009.

[2] J. O. Ukpata and M. E. Ephraim, "Flexural and tensile strength properties of concrete using lateritic sand and quarry dust as fine aggregate," J. Eng. Appl. Sci., vol. 7, no. 3, pp. 324-33, 2012.

[3] R. A. Silva, E. Soares, D. V. Oliveira, T. Miranda, N. M. Cristelo, and D. Leitão, "Mechanical characterisation of dry-stack masonry made of CEBs stabilised with alkaline activation," Constr. Build. Mater., vol. 75, 2015.

[4] A. S. Muntohar, "Engineering characteristics of the compressed-stabilized earth brick," Constr. Build. Mater., vol. 25, no. 11, pp. 4215-4220, 2011.

[5] P. J. Walker and Strength, "Durability and shrinkage characteristics of cement stabilised soil blocks," Cem. Concr. Compos., vol. 17, no. 4, pp. 301-310, 1995.

[6] P. J. Walker, "Strength and erosion characteristics of earth blocks and earth block masonry," J. Mater. Civ. Eng., vol. 16, no. 5, pp. 497-506, 2004.

[7] BS 3921:1985, "Specification for Clay bricks". British Standards Institute 1985.

[8] ASTM C140, "Standard test methods for sampling and testing concrete masonry units and related units", ASTM standards. 2015.

[9] ASTM C67, "Standard Test Methods of Sampling and Testing Brick and Structural Clay Tile", ASTM standards. 2014

[10] A. W. Hendry, B. P. Sinha, and S. R. Davies, "Design of masonry structures." E \& FN Spon. 2004.

[11] ASTM C90, "Standard Specification for Loadbearing Concrete Masonry Units", ASTM standards. (2014)

[12] Wheeler, Geoffrey, "Interlocking Compressed Earth Blocks Volume II. Manual of Construction.” Center for Vocational Building Technology, Thailand 110, 2005. 